\title{
The Need of Land for Industry and Housing as a Trigger Development on Modern Society
}

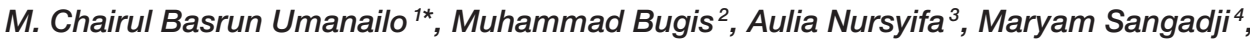 \\ Esther Kembauw ${ }^{5}$, Andries Lionardo ${ }^{6}$ and Chairun Nasirin ${ }^{7}$ \\ ' Universitas lqra Buru, Namlea, Indonesia, ${ }^{2}$ Fakultas Ekonomi Program Studi Ekonomi Pembangunan, Pamulang University, \\ Tangerang, Indonesia, ${ }^{3}$ Fakultas Keguruan dan IImu Pendidikan, Program Studi Pancasila dan Kewarganegaraan, \\ Tangerang, Indonesia, ${ }^{4}$ Fakultas Ekonomi Program Studi Ekonomi Pembangunan, University of Pattimura, Ambon, \\ Indonesia, ${ }^{5}$ Fakultas Pertanian, Program Studi Agribisnis, Tangerang, Indonesia, ${ }^{6}$ Fakultas IImu Sosial dan IImu Politik, \\ Program Studi IImu Komunikasi, Sriwijaya University, Palembang, Indonesia, ${ }^{7}$ Program Studi Ilmu Keperawatan, College of \\ Health Sciences (Sekolah Tinggi llmu Kesehatan), Mataram, Indonesia
}

Keywords: village, landlord, farmer, rational choice, conversion

\section{INTRODUCTION}

OPEN ACCESS

Edited by:

Tapan Kumar Nath,

University of Nottingham Malaysia

Campus, Malaysia

Reviewed by:

Mohammed Jashimuddin,

University of Chittagong, Bangladesh

*Correspondence:

M. Chairul Basrun Umanailo chairulbasrun@gmail.com

Specialty section:

This article was submitted to Land, Livelihoods and Food Security, a section of the journal Frontiers in Sustainable Food Systems

Received: 28 April 2021

Accepted: 16 July 2021

Published: 12 August 2021

Citation:

Umanailo MCB, Bugis $M$, Nursyifa $A$, Sangadji $M$, Kembauw E, Lionardo $A$ and Nasirin C (2021) The Need of

Land for Industry and Housing as a

Trigger Development on Modern

Society.

Front. Sustain. Food Syst. 5:701981

doi: 10.3389/fsufs.2021.701981
The history of a village in Indonesia is always framed by kinship, homogeneity, and a simple institutional structure. In agriculturally based rural communities, people used to work hard but feel relief from working within the framework of agricultural circles. At the busiest times, the extended family is usually unable to cultivate all the land or fields. During this period, people can hire additional people or ask for help from villagers (Zargustin et al., 2018). This can be found in Ngringo Village (Kanto et al., 2020). Village development with rice and livestock-based economic growth and pride at each harvest period is of little value, but the owners enjoy it very much.

What happens if a village is considered to have resources, as Ngringo Village currently has? Previously, we understood the village community as explained by Soejono Soekanto (Soekanto, 2001) that, in essence, rural communities are gradual. People in one village have a closer relationship with the people in their village than people in other villages. Group life is based on the kinship system. Although they work as carpenters, tile and brick makers, and construction workers, villagers generally have a livelihood in agriculture (Geertz, 1974; Scott, 1998; White, 2007). Society is characterized by interactions, unique patterns of behavior in all aspects of good and sustainable life, and a sense of identity toward the group, where the individual concerned becomes a member of the group (Yap and $\mathrm{Ng}$, 2018). Thus, of course, the Ngringo community will experience changes and will no longer be what Soejono Soekanto, Clifford Geertz, James Scott, and Thomas Ben White previously said.

Farmers are visualized as actors in land conversion. However, in real conditions, this conversion process occurs due to several factors such as geographical location, land availability, community acceptance of the entry of industry, and new economic location. Regarding the situation in Ngringo Village, the book entitled "Population Principles" written by Malthus states that human development is faster than the production of agricultural products to meet human needs. The amount of agricultural land in Ngringo Village as one of the leading production factors has remained even reduced drastically; agricultural land will be reduced due to building housing, factories, and other infrastructure. This situation then brought changes in society. Spencer distinguished four stages of human evolution: multiplication or addition stage, complexification stage, division or differentiation stage, and integration stage. 


\section{LAND SALES AS TRIGGER OF RURAL MODERNIZATION}

The increasing demand for land at high prices makes it more likely that farmers in Ngringo Village will sell or even offer land owned by their family or close relatives for sale. As a result, they will lose their main job as farmers. At the global level of rural modernization, the general restructuring of the rural economy can be seen in the agricultural sector. The impact of modernization brought substantial changes to the development of the agricultural industry (Ploeg et al., 2000). Modernization does not mean that farmers lose their jobs as farmers by selling agricultural land and improving the agricultural sector. Farmers who sell land will lose welfare in the long term because farmers will lose productivity assets (Zhang and Donaldson, 2013).

The focus of rural development in modern life is to improve the living standards of rural communities, develop agricultural production, and develop the village environment (Looney, 2012). Through the basic ideas of farmer's morals and economic arguments, James Scott reveals the short and powerful life of a farmer. The moral economy arises as a result of the central financial dilemma faced by most farming households (Lester et al., 2013). Because they live so close to the subsistence limit and keep up with changing weather and demands from outsiders, it seems that the Ngringo people do not seem to fully accept it. Precisely because they are approaching the limit of subsistence, their reason, as stated by Popkin, is the economic morality of a farmer who lives above the subsistence line, namely, with norms that prioritize self-safety and dare to take risks. In this regard, Popkin believes that farmers basically want to improve their economy and are willing to take risks. According to Popkin, farmers are full of profit-and-loss calculations, not only humans who are bound by moral values. Thus, when they take action in their choice, it is not because the capitalistic market economy threatens their "tradition" but because they want to get a chance to live in the new economic order. Farmers want to gain access to markets, become rich, and even adopt profit-and-loss practices.

Problems in selling land by farmers in Ngringo Village initially occurred because of the need to switch to commodities. Most of them sell agricultural land, which then buy new land outside the village at a much cheaper price; this condition will certainly be contrary to most of the community. Theories that reveal the traditional mindset and actions of rural communities and farmers such as Scott (1978) with Economic Subsistence (safety first strategy according to farmers can rule out options that contain the risk of significant losses that can endanger subsistence), Emile Durkheim (Marks, 1974) with anomie (rapid changes in society due to the increasing division of labor resulting in a confusion of norms and an increasing number of impersonalities in social life, ultimately resulting in the collapse of social standards that govern behavior), and Herbert Spencer of the theory of social evolution that assumes that society grows through individual development to unite the community group (Offer, 2019). Societies will change through mergers, meaning that the more they are connected, the more groups can coexist. The increasing needs of the community make people decide to sell agricultural land. Moreover, the decision was taken together so that changes occur in rural communities.

\section{DISCUSSION}

The action of land use changes when associated with rational choice theory; then, these conditions will encourage individuals who have a desire with the aim of expressing preferences. They act specifically due to constraints and based on information about the conditions in which they work. At the same time, the relationship between choice and rule can be seen in purely technical terms as a relation of means to ends. Since individuals cannot achieve all the things they want, for that, they must also choose ways to achieve these goals.

The facts show that there is a decrease in agricultural land production in Ngringo Village, which results in minimal irrigation conditions, so the choice to sell and find new land outside Ngringo Village is the right decision; this condition is in line with rationality. Rational choice theory argues that individuals should anticipate the outcomes of alternative actions and calculate the best for them. Wise individuals choose the alternative that will give them the most satisfaction. The social change proposed by Tönnies (1925) supports the phenomenon in Ngringo Village where Tönnies sees that the difference is based on two concepts, namely, Gemeinschaft of Place (Locality) and Gemeinschaft of mind (Heberle, 1937). Tönnies sees that the locality of Gemeinschaft can change when community interactions show capitalist activity to illustrate global changes (Inglis, 2009). Changing the mindset of the villagers to change their lives by selling land.

The sale and purchase of land in Ngringo Village is carried out by farmers, although at first each individual has the right to his land; then, it is switched to someone else. Can the pattern of inheritance distribution or the fulfillment of family needs occur? One-sidedly, the land owner switches the ownership rights to someone else. Based on the rational choice theory, this is because each individual wants to optimize or maximize his interests. Thus, it can be said that authority is the exchange of rights to control the actions of others. Coleman states that both collective and individual actors have goals. In social structures, such as organizations, individual actors may pursue their personal goals that may differ from collective goals. These conflicts of interest help us understand the sources of problems within institutions (Coleman, 1965). Here, collective actors have a vital role in acting for individual gain or loss.

The social system of the Ngringo Village community produces corporate actors, control, and sales of land. Ease of transaction is a pattern of actors to legitimize land sales. The role of corporate actors can be assessed from the sovereignty that exists in individuals. The existing social system can recognize its main interests (Granovetter, 1978). We can determine how well collective actors perform if the current social system can understand the individual's primary interests.

At the macrolevel, the rational choice theory assumes that human action has goals and objectives that are guided by a wellordered hierarchy of preferences. This naturally means that the 
actor takes into account priorities in choosing an action and also calculate the cost for each behavior and try to maximize self-confidence. In line with this assumption, the conversion conditions in Ngringo Village have presented similarities in several respects.

Landowners sell land for housing and industry. Like the preferences that the Ngringo Village community has to take advantage in achieving, but not all individuals in the Ngrino Village community have succeeded in maximizing these choices. The actors (landowners) want changes in resources structure; they sell land for school purposes and working capital. This situation shows that the actor has considered the actions to be taken to achieve the main goal of improving the family's standard of living and social status in order to maximize its resources.

The social system of the Ngringo Village community, which allows the sale and purchase of land, can be analyzed as a phenomenon that has previously been studied. The phenomenon of switching individual rights to others generates authority and creates a belief system; This is where the actor must think about the collectivity because it is no longer a mere actor's action but a collective action. An actor may not act based on his interests at this stage, but they must work on the common good (collectivity). However, in reality, actors do not always carry out activities as desired. For example, one of the agricultural lands has not been developed because the owner did not sell the location of the land. This condition causes delays in the construction of factories at that location.

The condition of land conversion threatens the existence of the farming community in Ngringo Village, shifting the orientation of the community toward the use of agricultural land from the social dimension to the economic level. The land that was originally used for daily livelihoods eventually changed according to the preferences they had. As a result, a situation of dependence arises on economic penetration from outside the village as a result of housing and industrial development. At the same time, freedom is meant to manage the resources at their disposal (Smelser and Swedberg, 2010; White, 2019).

The situation in Ngringo Village, which creates opportunities for industrial and housing development, demonstrates their

\section{REFERENCES}

Coleman, J. S. (1965). James S. Coleman. NASSP Bull. 49, 49-60. doi: $10.1177 / 019263656504929804$

Fritzsche, P., and Fukuyama, F. (1992). The end of history and the last man. Am. Hist. Rev. 97:817. doi: 10.2307/2164782

Geertz, C. (1974). "From the Native's Point of View": on the nature of anthropological understanding. Bull. Am. Acad. Arts Sci. 28:26. doi: $10.2307 / 3822971$

Granovetter, M. (1978). Threshold models of collective behavior. Am. J. Sociol. 83, 1420-1443. doi: 10.1086/226707

Heberle, R. (1937). The sociology of ferdinand tonnies. Am. Sociol. Rev. 2, 9-25. doi: $10.2307 / 2084562$

Inglis, D. (2009). Cosmopolitan sociology and the classical canon: ferdinand Tönnies and the emergence of global Gesellschaft. Br. J. Sociol. 60, 813-832. doi: $10.1111 /$ j.1468-4446.2009.01276.x position as a transitional society. Transitional societies lead to transitions in culture, behavior, systems, habits, etc. (Marks, 1974; Fritzsche and Fukuyama, 1992; Offer, 2019). Transitional society has begun to leave the old culture but has not fully adopted the new culture. Shifting is a natural thing to happen if it is done in a better and positive direction. The change from traditional society to transitional society is characterized by historical transformations due to differences in economic and social systems (Popkin, 1980; Scott et al., 2018). Changes that arise as a result of a transitional society are the decline in kinship values in society, traditional methods and traditional culture adapted to the new political system, manpower based on scientific specialization, and society more open to the times.

We will see Weber's approach to social change more clearly in his account of the birth of capitalism, as written in "The Protestant Ethic and the Spirit of Capitalism." The essence of Weber's description of capitalism is the orientation of rational thought among society toward economic benefits. According to Weber, a society can be called a capitalist society if its citizens consciously aspire to gain profit or wealth, which is considered ethical. This means that society provides legitimacy or recognition that is ethical and healthy. The author assumes that the action of land conversion carried out by land owners in Ngringo Village is a rational thought to gain profits. They do it consciously so that it can be said that the Ngringo village community is constructed into a capitalist society called by Marx Weber.

\section{AUTHOR CONTRIBUTIONS}

MB: planning and developing methods in studies and research in Ngringo Village. AN: collecting data and conducting interviews. MU: do the drafting of articles until the submission process. EK: help analyze the findings and help draft articles. MS: participate in making observations and help analyze the findings. AL: provide input and participate in compiling and improving the article. CN: help process data and perform similarity analysis in articles. All authors contributed to the article and approved the submitted version. 
Popkin, S. (1980). The rational peasant-the political economy of peasant society. Theory Soc. 9, 411-471. doi: 10.1525/9780520341623

Scott, J. C. (1978). The Moral Economy of the Peasant. Rebellion and Subsistence in Southeast Asia. Constitution in Law and Overseas. New Haven, CT:https:// www.jstor.org/publisher/yale Yale University Press.

Scott, J. C. (1998). James C. Scott. Foreign Affairs.

Scott, K., Rowe, F., and Pollock, V. (2018). Creating the good life? a wellbeing perspective on cultural value in rural development. J. Rural Stud. 59, 173-182. doi: 10.1016/j.jrurstud.2016.07.001

Smelser, N. J., and Swedberg, R. (2010). "The handbook of economic sociology," in The Handbook of Economic Sociology, eds N. J. Smelser and R. Swedberg (Princeton, NJ: https://www.degruyter.com/search?query\& publisherFacet $=$ Princeton $\$+\$$ University $\$+\$$ Press Princeton University Press), 748.

Soekanto, S. (2001). Sosiologi Sebagai Pengantar. Jakarta: Rajawali Pers.

Tönnies, F. (1925). Gemeinschaft und Gesellschaft 1. Kant Stud. 150-155. doi: 10.1515/kant.1925.30.1-2.149

White, B. (2007). Clifford geertz: singular genius of interpretive anthropology. Dev. Change 38, 1187-1208. doi: 10.1111/j.1467-7660.2007.00460.x

White, B. T. (2019). Refuge and history. Migr. Soc. 2, 107-118. doi: $10.3167 /$ arms.2019.020111

Yap, J. B. H., and Ng, X. H. (2018). Housing affordability in Malaysia: perception, price range, influencing factors and policies. Int. J. Hous. Mark. Anal. 11, 476-497. doi: 10.1108/IJHMA-08-2017-0069
Zargustin, D., Mufti, M., and Lidar, S. (2018). Pengentasan Kemiskinan Melalui Usaha Agroindustri Di Kecamatan Kampar Kabupaten Kampar Provinsi Riau. J. Agribus. 66-72. doi: 10.31849/agr.v18i2.768

Zhang, Q. F., and Donaldson, J. A. (2013). China's Agrarian reform and the privatization of land: a contrarian view. J. Contemp. China 20, 255-272. doi: 10.1080/10670564.2012.734081

Conflict of Interest: The authors declare that the research was conducted in the absence of any commercial or financial relationships that could be construed as a potential conflict of interest.

Publisher's Note: All claims expressed in this article are solely those of the authors and do not necessarily represent those of their affiliated organizations, or those of the publisher, the editors and the reviewers. Any product that may be evaluated in this article, or claim that may be made by its manufacturer, is not guaranteed or endorsed by the publisher.

Copyright (c) 2021 Umanailo, Bugis, Nursyifa, Sangadji, Kembauw, Lionardo and Nasirin. This is an open-access article distributed under the terms of the Creative Commons Attribution License (CC BY). The use, distribution or reproduction in other forums is permitted, provided the original author(s) and the copyright owner(s) are credited and that the original publication in this journal is cited, in accordance with accepted academic practice. No use, distribution or reproduction is permitted which does not comply with these terms. 